\title{
gChromatography-Free Synthesis of Corey's Intermediate for Tamiflu
}

Makoto Furutachi, Naoya Kumagai, Takumi Watanabe*, Masakatsu Shibasaki*

Institute of Microbial Chemistry (BIKAKEN), Tokyo, 3-14-23 Kamiosaki, Shinagawa-ku, Tokyo

141-0021, Japan
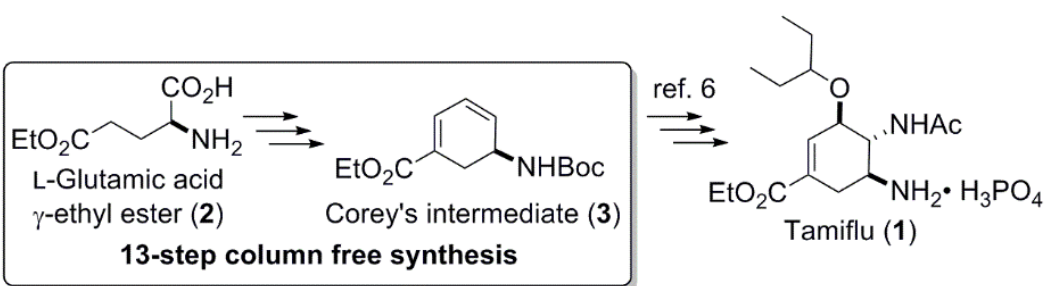

\section{(Graphical Abstract)}

Keywords: Tamiflu, Stereoselective synthesis, Chromatography-free synthesis, Corey's intermediate

ABSTRACT: Column chromatography-free stereoselective synthesis of Corey's intermediate for Tamiflu (oseltamivir phosphate) was achieved, starting from L-glutamic acid $\gamma$-ethyl ester. The reagents and solvents used in the reaction scheme are industrially tractable, rendering the synthesis a potential starting point for process research.

* Corresponding authors. tel.: +81 33441 4173; fax: +81 334417589 (T.W.); tel.: +81 33447 7779; fax: $\quad+81334417589 \quad$ (M.S.); e-mail addresses: twatanabe@bikaken.or.jp (T.W.), mshibasa@bikaken.or.jp (M.S.). 


\section{Introduction}

Seasonal influenza virus infection in humans threatens the quality of life and negatively impacts the economy. Vaccination is the most effective method of preventing pathogenic spread, but it can be rendered ineffective by genetic mutation of the virus. Further, highly virulent mutants could cause a pandemic and high mortality, as exemplified by three historical influenza pandemics, the Spanish flu in 1918, the Asian flu in 1957, and the Hong Kong flu in 1968.

The use of anti-influenza drugs is another powerful option to combat these pathogens, and several medicines of this class are available in the market. Among anti-influenza drugs, only Tamiflu (1, Scheme 1), an inhibitor of influenza viral neuraminidase developed by Gilead Science ${ }^{1}$ and Roche,${ }^{2}$ can be orally administered, and, due to the ease of usage, it is the most commonly prescribed anti-influenza drug in clinical use. Although the process route is carefully established and unarguably efficient, alternative synthetic routes toward Tamiflu have been reported by many research groups ${ }^{3,4}$ in response to concerns regarding the supply of shikimic acid, the starting material of the current manufactured synthesis of Tamiflu. 


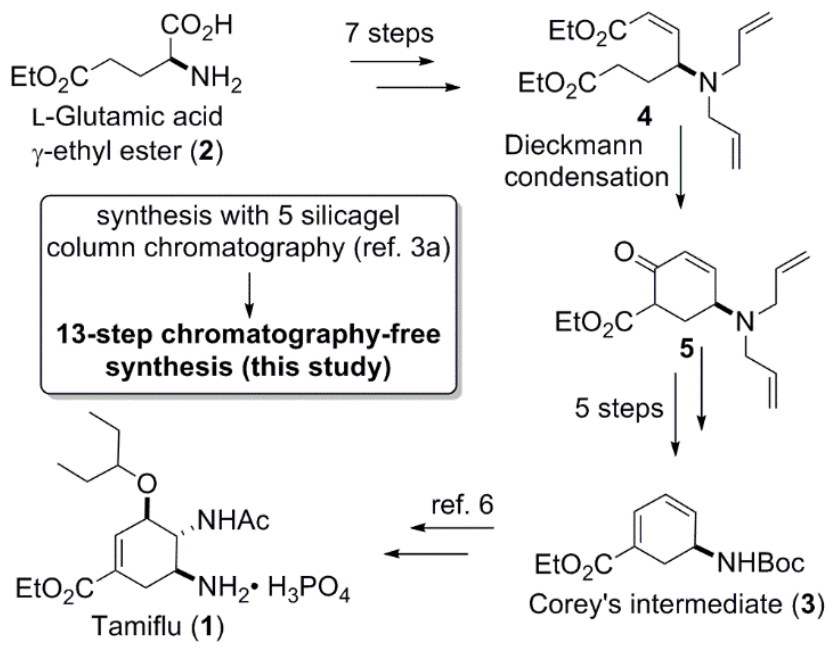

Scheme 1. Formal total synthesis of Tamiflu: glutamate route.

We previously reported syntheses of Tamiflu using several approaches, taking advantage of a variety of catalytic asymmetric reactions to address key stereochemical issues: nucleophilic opening of meso-aziridine and the Diels-Alder reaction. ${ }^{5}$ More recently, we completed a formal total synthesis of Tamiflu by targeting "Corey's intermediate" $(\mathbf{3})^{6}$ as the synthetic goal. In the present study, we used a Dieckmann condensation reaction to construct a six-membered ring core (5), for which the acyclic substrate $\mathbf{4}$ was prepared in a stereo-controlled manner according to two different strategies: a catalytic asymmetric three-component reaction; and use of L-glutamic acid $\gamma$-ethyl ester $\mathbf{2}$ as a chiral starting material (>99\% ee). While the catalytic asymmetric three-component reaction produced a modest level of enantioselectivity, up to $78 \%$ ee, the use of L-glutamic acid $\gamma$-ethyl ester 2 as a chiral starting material to retain its enantiopurity during the entire process to give Corey's intermediate in 13 steps. $^{7}$ The results indicated that "the glutamate route" was a good starting point for further elaboration to an industrial-scale synthesis, and prompted us to optimize the scheme 
toward this end (Scheme 1). Although the chemical yield of each step in the synthesis should be better than moderate, most of the steps required silica gel column chromatography, which is not practical for industrial-scale synthesis. In addition, this route includes reagents and conditions that are unacceptable for industrial processes, including highly flammable ( $\mathrm{Et}_{2} \mathrm{\Theta}, n$ hexane) or toxic $\left(\mathrm{CH}_{2} \mathrm{Cl}_{2}\right)$ solvent, an expensive reagent (LHMDS), volatile and corrosive reagent $\left(\mathrm{HCO}_{2} \mathrm{H}\right)$, an explosive reagent $\left(\mathrm{HClO}_{4}\right)$, extremely low reaction temperature $\left(-78^{\circ} \mathrm{C}\right)$, long reaction time $(2$ days $)$, and reactions that emit an unpleasant odor (Doering-Parikh oxidation).

Herein, we report a column chromatography-free synthesis of "Corey's intermediate" for the synthesis of Tamiflu by thorough optimization of the previously reported glutamate route, which relies on liquid-liquid partition and recrystallization as purification methods to avoid the use of silica gel column chromatography. In the present synthesis, many of the problematic steps for process research were updated to more preferable conditions for process development.

\section{Results and discussion}




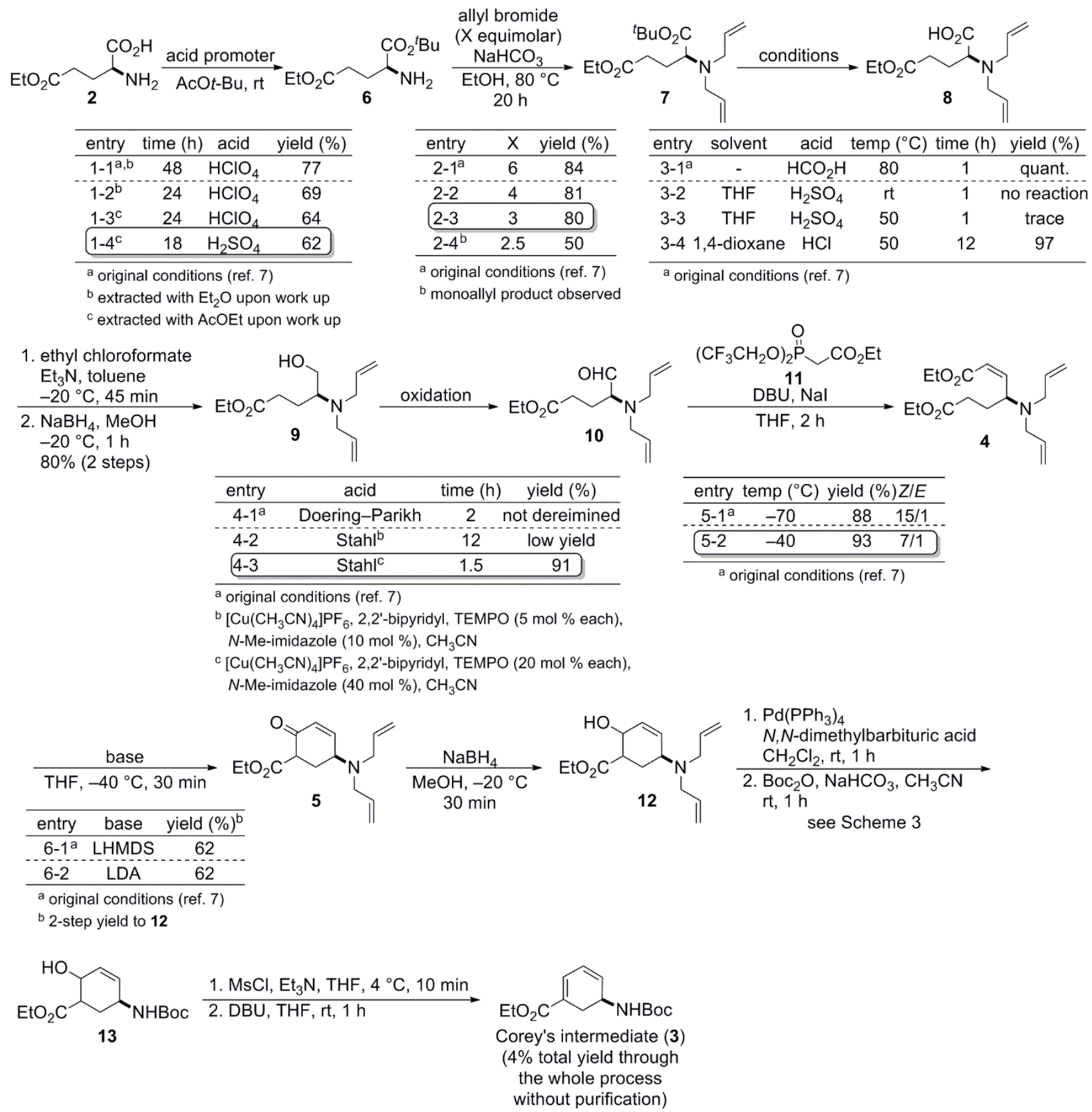

Scheme 2. Chromatography-free synthesis of Corey's intermediate for the synthesis of Tamiflu.

The glutamate route commences with $\alpha$-esterification of L-glutamic acid $\gamma$-ethyl ester $\mathbf{2}$ by acid-promoted transesterification with $\mathrm{AcO} t$-Bu (Scheme 2). ${ }^{8}$ In the original procedure, $\mathrm{HClO}_{4}$ (entry 1-1), an explosive and strong oxidant, was used as an acidic promoter. While the usual esterification conditions comprising an alcoholic solution with a more conventional protic acid 
suffered from low conversion (data not shown), $\mathrm{HClO}_{4}$ was replaced with $\mathrm{H}_{2} \mathrm{SO}_{4}$ to afford the corresponding $t$-butyl ester 6 (entry 1-4). The reaction time was shortened to $18 \mathrm{~h}$, and AcOEt could be used instead of $\mathrm{Et}_{2} \mathrm{O}$ for extraction of the product upon work-up, without a substantial loss of chemical yield.

In the next diallylation of the primary amino group, 3 equimolar amounts of allyl bromide (1.5-fold of the theoretically required amount, entry 2-3) showed satisfactory conversion to 7 , which enabled complete removal of the reagent and byproducts during simple work-up with filtration and evaporation. When allyl bromide was further decreased to 2.5 equimolar amounts, the reaction did not complete within $20 \mathrm{~h}$ (entry 2-4). The thus-optimized reaction conditions produced a relatively clean crude mixture, making silica gel chromatography unnecessary at this stage.

In the original protocol, the subsequent acid-mediated deprotection of $t$-butyl ester to the corresponding carboxylic acid $\mathbf{8}$ required a large excess of volatile and corrosive $\mathrm{HCO}_{2} \mathrm{H}$ (also used as the solvent, entry 3-1). Although $\mathrm{H}_{2} \mathrm{SO}_{4}$ as an acidic component was not effective (entries 3-2 and 3), the desired carboxylic acid $\mathbf{8}$ was obtained in $97 \%$ yield using $4 \mathrm{M}$ solution of $\mathrm{HCl}$ in 1,4-dioxane with gentle warming at $50{ }^{\circ} \mathrm{C}$ for $12 \mathrm{~h}$ (entry 3-4). Chemoselective reduction of the carboxyl group to the primary alcohol 9 via mixed anhydride ${ }^{9}$ was then achieved according to the previously reported conditions, and no chromatography was needed to attain the purity required for the subsequent steps. With the primary alcohol 9 in hand, the two-step procedure to access a substrate for Dieckmann condensation to furnish a skeletal six-membered ring of Tamiflu was applied: originally, 
Doering-Parikh oxidation $\left(\mathrm{SO}_{3} \cdot\right.$ pyridine, $\mathrm{Et}_{3} \mathrm{~N}$, DMSO, entry 4-1) was followed by the $Z$-selective Horner-Wadsworth-Emmons (HWE) reaction with phosphonate 11, reported by Still and Gennari. ${ }^{10}$ Although the reaction sequence effectively afforded the desired olefin $\mathbf{4}$ in $88 \%$ yield in a highly Z-selective manner $(Z / E=15 / 1)$, the Doering-Parikh oxidation inevitably outputs foul-smelling $\mathrm{Me}_{2} \mathrm{~S}$ as a byproduct, and the HWE olefination was performed at $-78{ }^{\circ} \mathrm{C}$ (entry $5-1$ ), which is too low to be practical at an industrial scale. The oxidation problem was resolved by changing the conditions to a copper-catalyzed TEMPO-promoted methodology, which was recently reported by Stahl. ${ }^{11}$ Although the catalyst loading had to be increased to 20 mol \%, clean conversion to $\mathbf{1 0}$ was observed in $1.5 \mathrm{~h}$ (entries 4-2 and 3). After thorough optimization, the succeeding HWE process was effective at $-40{ }^{\circ} \mathrm{C}$, at the slight expense of Z-selectivity $(Z / E=7 / 1)$, which essentially had no detrimental effects in the subsequent reactions (entry 5-2). Purification by silica gel chromatography, performed in the previous report, was not necessary.

A key reaction of this synthetic route, Dieckmann condensation of the crude material of diester 4, was conducted with lithium diisopropylamide (LDA) as a base (entry 6-2), which was ehanged from instead of lithium hexamethyl disilazide (LHMDS; entry 6-1), providing the same efficiency to give a cyclohexenone derivative 5. A 1,2-reduction of the crude material from each condition resulted in the same chemical yield over two steps (62\%, entries 6-1 and 2). 


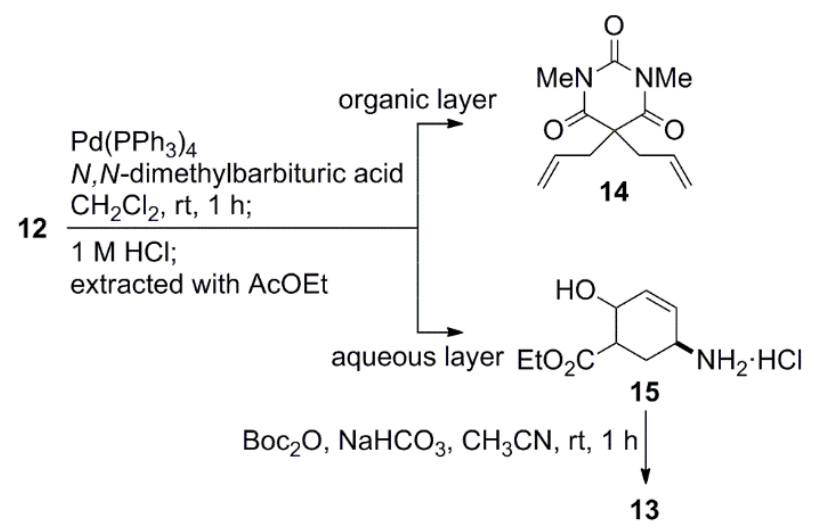

Scheme 3. Protocol for the synthesis of $\mathbf{1 3}$ from $\mathbf{1 2 .}$

Exchange of the protecting group of the resultant cyclohexenol $\mathbf{1 2}$ from diallyl to Boc exhibited efficient conversion, but it was the most difficult process to avoid silica gel column chromatography purification (Scheme 3). Subsequent elimination of the secondary hydroxyl group gave many byproducts, thereby affording a low yield of Corey's intermediate (3), which definitely required silica gel column chromatography purification. It was particularly difficult to eliminate the stoichiometric amount of diallyl barbiturate during the deallylation work-up, as well as to remove superfluous $\mathrm{Boc}_{2} \mathrm{O}$ after reprotection of the primary amine. Through extensive investigation of the deprotection, a tactic liquid-liquid partition afforded the substrate for Boc-protection with satisfactory purity: the free amine product was treated with $1 \mathrm{M} \mathrm{HCl}$ to form the corresponding salt 15 to be dissolved in water, and the barbiturate derivative 14 was washed away with extraction by organic solvent. The aqueous solution of the salt could be directly used for introduction of the Boc group under biphasic conditions. The remaining $\mathrm{Boc}_{2} \mathrm{O}$ was dissolved in $n$-hexane and discarded to give the resulting $\beta$-hydroxy ester $\mathbf{1 3}$ as a solid in a pure form. Although the yield was modest after 
purification by recrystallization (33\% in 2 steps), ${ }^{12}$ these modifications would be key to realizing a column-free reaction sequence.

Final elimination of the hydroxyl group via a mesylate was uneventful, even while using THF, which was replaced the originally used volatile toxic solvent, $\mathrm{CH}_{2} \mathrm{Cl}_{2}$, to provide Corey's intermediate (3) in quantitative yield (total yield of 4\%). The thus-obtained samples showed satisfactory purity without silica gel chromatography even after the last step, as shown in the supporting information.

\section{Summary}

Column chromatography-free synthesis of Corey's intermediate for the synthesis of Tamiflu was completed. The newly refined synthetic scheme used reagents and reaction conditions more suitable for applying to process research in the next stage of development. Further optimization of this route to improve the yield of each step, and to increase the cost-effectiveness and benignity of all of the conditions is ongoing.

\section{Experimental}

\subsection{General}


All reactions were performed in round-bottom flasks with a Teflon-coated magnetic stirring bar under air unless otherwise noted. All work-up and purification procedures were performed with reagent grade solvents under ambient atmosphere. Infrared (IR) spectra were recorded on a JASCO FT/IR 4100 Fourier-transform IR spectrophotometer. NMR was recorded on a JEOL ECS-400 400 MHz spectrometer. For ${ }^{1} \mathrm{H}$ NMR (400 MHz), chemical shifts of protons are reported in parts per million downfield from tetramethylsilane and are referenced to residual protium in the NMR solvent $\left(\mathrm{CDCl}_{3}, \delta 7.24 \mathrm{ppm}\right)$. For ${ }^{13} \mathrm{C}$ NMR $(100 \mathrm{MHz})$, chemical shifts are reported in a scale relative to the NMR solvent $\left(\mathrm{CDCl}_{3}, \delta 77.0 \mathrm{ppm}\right)$ as an internal reference. The NMR data are reported as follows: chemical shifts, multiplicity ( $\mathrm{s}$ : singlet, d: doublet, dd: doublet of doublets, $\mathrm{t}$ : triplet, q: quartet, m: multiplet), coupling constant $(\mathrm{Hz})$, and integration. Optical rotation was measured using a $2-\mathrm{mL}$ cell with a 1.0-dm path length on a polarimeter. High-resolution mass spectra (ESI-Orbitrap) were measured on a Thermo Fisher Scientific LTQ Orbitrap XL. HPLC analysis was conducted on a JASCO HPLC system equipped with Daicel chiral-stationary-phase columns $(\phi 0.46 \mathrm{~cm} \times 25 \mathrm{~cm})$. THF, $\mathrm{CH}_{3} \mathrm{CN}$, and $\mathrm{CH}_{2} \mathrm{Cl}_{2}$ were purified by passing through a solvent purification system (Glass Contour).

\subsection{Synthesis of Corey's intermediate}

(S)-1-tert-Butyl 5-ethyl 2-aminopentanedioate (6). A solution of 95\% $\mathrm{H}_{2} \mathrm{SO}_{4}(5.077 \mathrm{~mL}, 90.00$ 
mmol) at $4{ }^{\circ} \mathrm{C}$ was added to a solution of L-glutamic acid $\gamma$-ethyl ester $2(8.760 \mathrm{~g}, 50.00 \mathrm{mmol})$ in $\mathrm{AcO} t$ - $\mathrm{Bu}(217.4 \mathrm{~mL})$. The resulting solution was warmed to room temperature and stirred for $18 \mathrm{~h}$, then $0.1 \mathrm{M}$ aqueous $\mathrm{HCl}(350.0 \mathrm{~mL})$ and AcOEt were sequentially added to the mixture. The aqueous phase was separated from the organic phase, and adjusted to $\mathrm{pH}=9$ with aqueous $\mathrm{Na}_{2} \mathrm{CO}_{3}$. The aqueous phase was extracted with AcOEt, and the organic layers were combined, washed with brine, dried over $\mathrm{Na}_{2} \mathrm{SO}_{4}$, and concentrated to afford the desired ester $\mathbf{6}$ as a pale yellow oil (7.190 g, $62 \%$ ). The crude product was NMR pure and was used directly in the next step without purification.

(S)-1-tert-Butyl 5-ethyl-2-(diallylamino)pentanedioate (7). Diester 6 (4.626 g, $20.00 \mathrm{mmol}$ ) was dissolved in EtOH (100.0 mL), and powdered $\mathrm{NaHCO}_{3}(6.721 \mathrm{~g}, 80.00 \mathrm{mmol})$ and allyl bromide $(5.186 \mathrm{~mL}, 60.00 \mathrm{mmol})$ were added at room temperature. The mixture was stirred under reflux for $20 \mathrm{~h}$, then cooled to room temperature, concentrated under reduced pressure, filtered through a Celite pad using AcOEt, and concentrated to give crude material containing 7 (estimated to be $80 \%$ yield), which was used directly in the next step without purification.

(S)-Ethyl 4-(diallylamino)-5-hydroxypentanoate (9). Diester 7 (20.00 mmol) was dissolved in $4 \mathrm{M}$ $\mathrm{HCl}$ in 1,4-dioxane $(400.0 \mathrm{~mL})$ and stirred at $50{ }^{\circ} \mathrm{C}$ for $12 \mathrm{~h}$. The reaction mixture was cooled to room temperature and concentrated under reduced pressure to afford the crude mixture containing $\mathbf{8}$. $\mathrm{Et}_{3} \mathrm{~N}(13.86 \mathrm{~mL}, 100.0 \mathrm{mmol})$, followed by ethyl chloroformate $(5.711 \mathrm{~mL}, 60.00 \mathrm{mmol})$, was added 
to the resultant residue in toluene $(400.0 \mathrm{~mL})$ at $-20{ }^{\circ} \mathrm{C}$. After $45 \mathrm{~min}, \mathrm{NaBH}_{4}(3.026 \mathrm{~g}, 80.00 \mathrm{mmol})$ was added in one portion. $\mathrm{MeOH}(133.3 \mathrm{~mL})$ was then added dropwise to the mixture over $30 \mathrm{~min}$ at $-20{ }^{\circ} \mathrm{C}$. The solution was stirred for an additional $15 \mathrm{~min}$ at $-20{ }^{\circ} \mathrm{C}$ and then quenched with cold water. After the mixture was warmed to room temperature, the organic solvents were evaporated under reduced pressure, and the product was extracted with AcOEt, washed with brine, dried over $\mathrm{Na}_{2} \mathrm{SO}_{4}$, and concentrated under reduced pressure to afford crude material containing 9 (estimated to be $72 \%$ yield over 2 steps), which was used directly in the next step without purification.

(S)-Ethyl 4-(diallylamino)-5-oxopentanoate $(\mathbf{1 0}) . \quad\left[\mathrm{Cu}(\mathrm{MeCN})_{4}\right] \mathrm{BF}_{4}^{-}(1.258 \mathrm{~g}, 4.000 \mathrm{mmol})$, 2,2'-bipyridyl (624.8 mg, $4.000 \mathrm{mmol})$, TEMPO (625.2 $\mathrm{mg}, 4.000 \mathrm{mmol}$ ), and 1-methylimidazole $(631.5 \mu \mathrm{L}, 8.000 \mathrm{mmol})$ were successively added to a solution of alcohol 9 (20.00 $\mathrm{mmol})$ in $\mathrm{CH}_{3} \mathrm{CN}$ $(100.0 \mathrm{~mL})$ at room temperature. The solution was stirred for $1.5 \mathrm{~h}$ at the same temperature and then quenched with water. The product was extracted with AcOEt, washed with brine, dried over $\mathrm{Na}_{2} \mathrm{SO}_{4}$, and concentrated under reduced pressure to afford crude material containing $\mathbf{1 0}$ (estimated to be $91 \%$ yield), which was used directly in the next step without purification.

(S)-Diethyl 4-(diallylamino)-(Z)-hept-2-enedioate (4). A solution of NaI (4.497 g, $30.00 \mathrm{mmol})$, DBU (4.178 mL, $28.00 \mathrm{mmol})$, and $\left(\mathrm{CF}_{3} \mathrm{CH}_{2} \mathrm{O}\right)_{2} \mathrm{P}(=\mathrm{O}) \mathrm{CH}_{2} \mathrm{CO}_{2} \mathrm{Et}$ (11) $(6.002 \mathrm{~mL}, 28.00 \mathrm{mmol})$ in THF (93.33 mL) was slowly added to a solution of $\mathbf{1 0}(20.00 \mathrm{mmol})$ in THF $(106.7 \mathrm{~mL})$ over $45 \mathrm{~min}$ 
at $-40{ }^{\circ} \mathrm{C}$. After the addition was completed, the mixture was stirred at the same temperature for an additional $15 \mathrm{~min}$. Then, the reaction mixture was quenched with cold water. After the mixture was warmed to room temperature, the product was extracted with AcOEt. The combined organic layers were washed with brine, dried over $\mathrm{Na}_{2} \mathrm{SO}_{4}$, and concentrated under reduced pressure to afford a crude material containing 4 (estimated to be $93 \%$ yield, $Z / E=7 / 1$ ), which was used directly in the next step without purification.

(5S)-Ethyl 5-(diallylamino)-2-hydroxycyclohex-3-enecarboxylate (12). A $1.13 \mathrm{M}$ THF solution of LDA (22.94 mL, $25.92 \mathrm{mmol})$ was slowly added to a stirred solution of 4 (8.640 mmol) in THF (20.26 mL) at $-40{ }^{\circ} \mathrm{C}$, and the mixture was stirred at the same temperature for $30 \mathrm{~min}$. The reaction mixture was then quenched with saturated aqueous $\mathrm{NH}_{4} \mathrm{Cl}$, warmed to room temperature, and the product was extracted with AcOEt. The combined organic layers were washed with brine, dried over $\mathrm{Na}_{2} \mathrm{SO}_{4}$, filtered, and concentrated to give crude $\mathbf{5}$ (keto-enol mixture), which was used for the next reaction without further purification. $\mathrm{NaBH}_{4}(653.7 \mathrm{mg}, 17.28 \mathrm{mmol})$ was added a stirred solution of crude $5(8.640 \mathrm{mmol})$ in $\mathrm{MeOH}(43.20 \mathrm{~mL})$ at $-20^{\circ} \mathrm{C}$, and the mixture was stirred for $30 \mathrm{~min}$ at the same temperature. After adding saturated aqueous $\mathrm{NH}_{4} \mathrm{Cl}$, the reaction mixture was warmed to room temperature, and $\mathrm{MeOH}$ was removed under reduced pressure. AcOEt was added, and the resulting aqueous layer was extracted with AcOEt. The combined organic layers were washed with brine, dried over $\mathrm{Na}_{2} \mathrm{SO}_{4}$, filtered, and concentrated to give crude 12 (estimated to be $62 \%$ yield over 2 
steps), which was used for the next reaction without further purification.

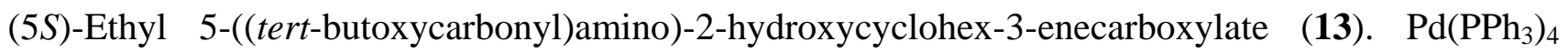
(619.3 mg, $0.5357 \mathrm{mmol}, 10 \mathrm{~mol} \%$ ) and $N, N$-dimethylbarbituric acid (5.017 g, $32.14 \mathrm{mmol})$ were successively added to a stirred solution of crude $12(5.357 \mathrm{mmol})$ in $\mathrm{CH}_{2} \mathrm{Cl}_{2}(26.79 \mathrm{~mL})$ at room temperature, and the mixture was stirred for $1 \mathrm{~h}$. Then, $1.0 \mathrm{M}$ aqueous $\mathrm{HCl}$ was added and washed with AcOEt. $\mathrm{Na}_{2} \mathrm{CO}_{3}(5.678 \mathrm{~g}, 53.57 \mathrm{mmol})$ and a $1.0 \mathrm{M}$ solution of $\mathrm{Boc}_{2} \mathrm{O}$ in AcOEt $(26.79 \mathrm{~mL}$, $26.79 \mathrm{mmol}$ ) were successively added to the aqueous phase at room temperature, and the mixture was stirred for $2 \mathrm{~h}$ at room temperature. After the addition of saturated aqueous $\mathrm{NaHCO}_{3}$, the aqueous layer was extracted with AcOEt. The combined organic layers were dried over $\mathrm{Na}_{2} \mathrm{SO}_{4}$, $n$-hexane was added (AcOEt : $n$-hexane $=1: 1$ ), filtered through thinly-layered silica gel, and concentrated to give a crude mixture, which was purified by recrystallization by $n$-hexane/AcOEt to afford 13 (234.7 mg, $0.8226 \mathrm{mmol}$, diastereomeric mixture, 4\% yield over 8 steps) as a pale yellow solid.

(S)-Ethyl 5-((tert-butoxycarbonyl)amino)cyclohexa-1,3-dienecarboxylate (3). $\mathrm{MsCl}(17.04 \mu \mathrm{L}$, $0.2200 \mathrm{mmol})$ and $\mathrm{Et}_{3} \mathrm{~N}(55.45 \mu \mathrm{L}, 0.4000 \mathrm{mmol})$ were successively added to a stirred solution of $\mathbf{1 3}$ $(57.06 \mathrm{mg}, 0.2000 \mathrm{mmol})$ in $\mathrm{THF}(1.000 \mathrm{~mL})$ at $4{ }^{\circ} \mathrm{C}$, and the mixture was stirred for $10 \mathrm{~min}$ at the same temperature. DBU $(89.53 \mu \mathrm{L}, 0.6000 \mathrm{mmol})$ was added to the mixture, and the mixture was 
stirred further for $1 \mathrm{~h}$ at room temperature. After the addition of $1 \mathrm{M} \mathrm{HCl}$, the aqueous layer was extracted with AcOEt. The combined organic layers were dried over $\mathrm{Na}_{2} \mathrm{SO}_{4}$, filtered, and concentrated to give Corey's intermediate $\mathbf{3}(55.77 \mathrm{mg}, 0.2086 \mathrm{mmol}$, quantitative yield) as a pale yellow oil. The crude product was NMR pure. Physicochemical data were identical to those previously reported, ${ }^{6}$ as follows. ${ }^{1} \mathrm{H} \mathrm{NMR}\left(\mathrm{CDCl}_{3}, 400 \mathrm{MHz}\right) \delta 7.03(\mathrm{~d}, J=3.9 \mathrm{~Hz}, 1 \mathrm{H}), 6.18-6.09$ (m, 2H), $4.61(\mathrm{~m}, 1 \mathrm{H}), 4.42(\mathrm{~m}, 1 \mathrm{H}), 4.20(\mathrm{q}, J=7.1 \mathrm{~Hz}, 2 \mathrm{H}), 2.76-2.61(\mathrm{~m}, 2 \mathrm{H}), 1.42(\mathrm{~s}, 9 \mathrm{H}), 1.29$ $(\mathrm{t}, J=7.1 \mathrm{~Hz}, 3 \mathrm{H}) ;{ }^{13} \mathrm{C} \mathrm{NMR}\left(\mathrm{CDCl}_{3}, 100 \mathrm{MHz}\right) \delta 166.8,154.9,132.7,131.7,127.0,124.8,79.5$, 60.6, 43.5, 28.8, 28.4, 14.3; IR (neat, $\mathrm{cm}^{-1}$ ) 3352, 2978, 1705; ESI-HRMS calcd for $\mathrm{C}_{14} \mathrm{H}_{21} \mathrm{NO}_{4} \mathrm{Na}$ $[\mathrm{M}+\mathrm{Na}]^{+} 290.1363$, found 290.1361; $[\alpha]_{\mathrm{D}}^{25}=-205.5\left(98.9 \%\right.$ ee, c 1.1, $\left.\mathrm{CHCl}_{3}\right)$, lit. $[\alpha]_{\mathrm{D}}^{25}=-217$ $\left(>99 \%\right.$ ee, c 1.1, $\left.\mathrm{CHCl}_{3}\right) ;{ }^{6} \mathrm{HPLC}(n$-hexane/2-propanol $=50 / 1, \mathrm{CHIRALPAK}$ AD-H, $1.0 \mathrm{~mL} / \mathrm{min}$, $254 \mathrm{~nm}) \mathrm{t}_{\mathrm{R}}=16.4 \min ($ minor), $19.3 \min$ (major).

\section{Acknowledgments}

M.S and M.F. are grateful to Adaptable and Seamless Technology Transfer Program through Target-driven R\&D, JST for financial support. The authors appreciate Dr. Hiroyuki Yamaguchi, Dr. Shinjiro Sumi, Mr. Tadashi Ishiyama, and Mr. Shinya Ikeda (Meiji Seika Pharma Co., Ltd.) for their valuable suggestions. The authors thank Ms. Chiharu Sakashita (BIKAKEN) for her technical assistance. The authors are thankful to Dr. Ryuichi Sawa, Ms. Yumiko Kubota, and Ms. Yuko Takahashi (BIKAKEN) for spectroscopic analysis. 


\section{Supplementary data}

${ }^{1} \mathrm{H}$ and ${ }^{13} \mathrm{C}$ NMR spectra, and HPLC data for 3 .

\section{References and notes}

1. Kim, C. U.; Lew, W.; Williams, M. A.; Liu, H. T.; Zhang, L. J.; Swaminathan, S.; Bischofberger,

N.; Chen, M. S.; Mendel, D. B.; Tai, C. Y.; Laver, W. G.; Stevens, R. C. J. Am. Chem. Soc. 1997, 119, 681.

2. (a) Karpf, M.; Trussardi, R. J. Org. Chem. 2001, 66, 2044. (b) Rohloff, J. C.; Kent, K. M.; Postich,

M. J.; Becker, M. W.; Chapman, H. H.; Kelly, D. E.; Lew, W.; Louie, M. S.; McGee, L. R.; Prisbe, E. J.; Schultze, L. M.; Yu, R. H.; Zhang, L. J. J. Org. Chem. 1998, 63, 4545. (c) Abrecht, S.; Harrington, P.; Iding, H.; Karpf, M.; Trussardi, R.; Wirz, B.; Zutter, U. Chimia 2004, 58, 621.

3. (a) Bromfield, K. M.; Graden, H.; Hagberg, D. P.; Olsson, T.; Kann, N. Chem. Commun. 2007, 3183. (b) Satoh, N.; Akiba, T.; Yokoshima, S.; Fukuyama, T. Angew. Chem. Int. Ed. 2007, 46, 5734.

(c) Satoh, N.; Akiba, T.; Yokoshima, S.; Fukuyama, T. Tetrahedron 2009, 65, 3239. (d) Shie, J.-J.; Fang, J.-M.; Wang, S.-Y.; Tsai, K.-C.; Cheng, Y.-S. E.; Yang, A.-S.; Hsiao, S.-C.; Su, C.-Y.; Wong, C.-H. J. Am. Chem. Soc. 2007, 129, 11892. (e) Chen, C.-A.; Fang, J.-M. Org. Biomol. Chem. 2013, 11, 7687. (f) Kipassa, N. T.; Okamura, H.; Kina, K.; Hamada, T.; Iwagawa, T. Org. Lett. 2008, 10, 815. (g) Trost, B. M.; Zhang, T. Angew. Chem. Int. Ed. 2008, 47, 3759. (h) Zutter, U.; Iding, H.; 
Spurr, P.; Wirz, B. J. Org. Chem. 2008, 73, 4895. (i) Shie, J.-J.; Fang, J.-M.; Wong, C.-H. Angew. Chem. Int. Ed. 2008, 47, 5788. (j) Matveenko, M.; Willis, A. C.; Banwell, M. G. Tetrahedron Lett. 2008, 49, 7018. (k) Ishikawa, H.; Suzuki, T.; Hayashi, Y. Angew. Chem. Int. Ed. 2009, 48, 1304. (l) Ishikawa, H.; Suzuki, T.; Orita, H. Uchimaru, T.; Hayashi, Y. Chem. Eur. J. 2010, 16, 12616. (m) Ishikawa, H.; Bondzic, B. P.; Hayashi, Y. Eur. J. Org. Chem. 2011, 6020. (n) Mukaiyama, T.; Ishikawa, H.; Koshino, H.; Hayashi, Y. Chem. Eur. J. 2013, 19, 17789. (o) Zhu, S.; Yu, S.; Wang, Y.; Ma, D. Angew. Chem. Int. Ed. 2010, 49, 4656. (p) Sullivan, B.; Carrera, I.; Drouin, M.; Hudlicky, T. Angew. Chem. Int. Ed. 2009, 48, 4229. (q) Werner, L.; Machara, A.; Hudlicky, T. Adv. Synth. Catal. 2010, 352, 195. (r) Mandai, T.; Oshitari, T. Synthesis 2009, 783. (s) Oshitari, T.; Mandai, T. Synlett 2009, 787. (t) Sun, H.; Lin, Y.-J.; Wu, Y.-L.; Wu, Y. Synlett 2009, 2473. (u) Osato, H.; Jones, I. L.; Chen, A.; Chai, C. L. L. Org. Lett. 2010, 12, 60. (v) Wichienukul, P.; Akkarasamiyo, S.; Kongkathip, N.; Kongkathip, B. Tetrahedron Lett. 2010, 51, 3208. (w) Ma, J.; Zhao, Y.; Ng, S.; Zhang, J.; Zeng, J.; Than, A.; Chen, P.; Liu, X.-W. Chem. Eur. J. 2010, 16, 4533. (x) Weng, J.; Li, Y.-B.; Wang, R.-B.; Li, F.-Q.; Liu, C.; Chan, A. S. C.; Lu, G. J. Org. Chem. 2010, 75, 3125. (y) Kamimura, A.; Nakano, T. J. Org. Chem. 2010, 75, 3133. (z) Ko, J. S.; Keum, J. E.; Ko, S. Y. J. Org. Chem. 2010, 75, 7006. (aa) Trost, B. M.; Zhang, T. Chem. Eur. J. 2011, 17, 3630. (ab) Trajkovic, M.; Ferjancic, Z.; Saicic, R. N. Org. Biomol. Chem. 2011, 9, 6927. (ac) Trajkovic, M.; Ferjancic, Z.; Saicic, R. N. Synthesis 2013, 45, 389. (ad) Werner, L.; Machara, A.; Sullivan, B.; Carrera, I.; Moser, M.; Adams, D. R.; Hudlicky, T.; Andraos, J. J. Org. Chem. 2011, 76, 10050. (ae) Oh, H.-S.; Kang, H.-Y. J. Org. Chem. 2012, 77, 
8792. (af) Rehak, J.; Hut'ka, M.; Latika, A.; Brath, H.; Almassy, A.; Hajzer, V.; Durmis, J.; Toma, S.;

Sebesta, R. Synthesis 2012, 44, 2424. (ag) Chavan, S. P.; Chavan, P. N.; Khairnar, L. B. RSC Adv. 2014, 4, 11417. For alternative approaches using (-)-shikimic acid as starting materials, see; (ah) Karpf, M.; Trussardi, R. Angew. Chem. Int. Ed. 2009, 48, 5760. (ai) Nie, L.-D.; Shi, X.-X. Tetrahedron Asymmetry 2009, 20, 124. (aj) Nie, L.-D.; Shi, X.-X.; Ko, K. H.; Lu, W.-D. J. Org. Chem. 2009, 74, 3970. (ak) Nie, L.-D.; Wang F.-F.; Ding, W.; Shi, X.-X.; Lu, X. Tetrahedron Asymmetry 2013, 24, 638.

4. For reviews, see; (a) Shibasaki, M.; Kanai, M. Eur. J. Org. Chem. 2008, 1839; (b) Farina, V.; Brown, J. D. Angew. Chem. Int. Ed. 2006, 45, 7330-7334; (c) Magano, J. Chem. Rev. 2009, 109, 4398; (d) Andraos, J. Org. Process. Res. Dev. 2009, 13, 161. (e) Magano, J.; Tetrahedron 2011, 67, 7875.

5. (a) Fukuta, Y.; Mita, T.; Fukuda, N.; Kanai, M.; Shibasaki, M. J. Am. Chem. Soc. 2006, 128, 6312. (b) Mita, T.; Fukuda, N.; Roca, F. X.; Kanai, M.; Shibasaki, M. Org. Lett. 2007, 9, 259; (c) Yamatsugu, K.; Kamijo, S.; Suto, Y.; Kanai, M.; Shibasaki, M. Tetrahedron Lett. 2007, 46, 1403; (d) Yamatsugu, K.; Yin, L.; Kamijo, S.; Kimura, Y.; Kanai, M.; Shibasaki, M. Angew. Chem. Int. Ed. 2009, 48, 1070; (e) Yamatsugu, K.; Kanai, M.; Shibasaki, M. Tetrahedron 2009, 65, 6017.

6. Yeung, Y.-Y.; Hong, S.; Corey, E. J. J. Am. Chem. Soc. 2006, 128, 6310.

7. Alagiri, K.; Furutachi, M.; Yamatsugu, K.; Kumagai, N.; Watanabe, T.; Shibasaki, M. J. Org. Chem. 2013, 78, 4019. 
8. Hu, J.; Miller, M. J. J. Am. Chem. Soc. 1997, 119, 3462.

9. Ishizumi, K.; Koga, K.; Yamada, S.-I. Chem. Pharm. Bull. 1968, 16, 492.

10. Still, W. C.; Gennari, C. Tetrahedron Lett. 1983, 24, 4405.

11. (a) Hoover, J. M.; Stahl. S. S. J. Am. Chem. Soc. 2011, 133, 16901. (b) Hoover, J. M.; Ryland, B.

L.; Stahl. S. S. J. Am. Chem. Soc. 2013, 135, 2357.

12. When the product was purified by silica-gel column chromatography in a previous attempt, the isolated yield was $87 \%$. 

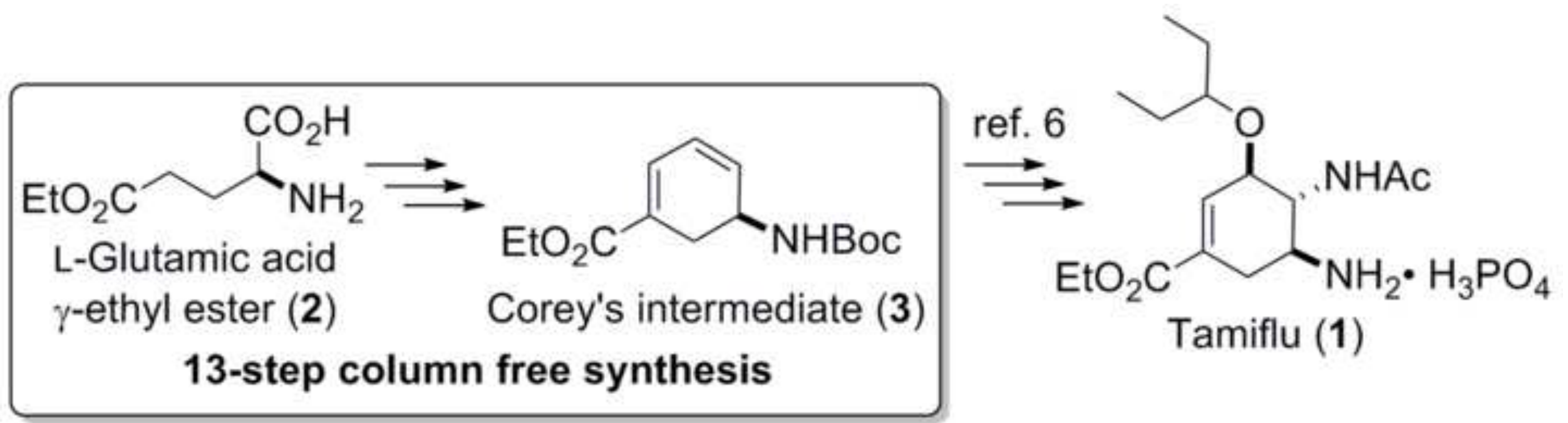